\title{
Tooth contact analysis of $x$-zero helical gears by the modification of the tooth trace
}

\author{
Sándor Bodzás
}

0000-0001-8900-2800

Department of Mechanical Engineering, Faculty of Engineering, University of Debrecen, Debrecen, 4028, Hungary

\begin{abstract}
The helical gear pairs are widely used in different mechanical constructs. The main advantage is the good efficiency and the low noise during the connection.

We have worked out a computer software with which the designing process of the helical gears could be eased. Based on the calculated gear parameters the CAD models of the elements could be prepared. Knowing of the geometries the assembly could be created based on the fixed freedom degrees and the elementary centre distance. We have designed five types of gear pairs. The differences are only the different tooth traces. All of other parameters have not been modified.

The aim of this research is the function between the tool trace and the mechanical parameters. Using of the TCA the mechanical parameters of the connecting elements on the contact zone could be analyses by different loads.

We have done this analysis which means we have analyzed the effect of the modified parameter for the normal stress, normal deformation and the normal elastic strain on the contact zone. Based on the results we have prepared diagrams for the analysis of the correlations between the changing parameters.

Before the real production the TCA is suggested because of the determination of the estimated mechanical parameters. If these parameters would not give required results it could be possible to return to the geometric designing process and modify the geometric parameters.
\end{abstract}

Keywords: Helical gear, tooth trace, TCA, CAD, normal

\section{* Corresponding author}

Sándor Bodzás

bodzassandor@eng.unideb.hu

Address: Department of Mechanical Engineering, University of Debrecen, Debrecen, 4028, Hungary

Tel: +36706002846

Researh Article
Received 13.02.2019

Revised $\quad 10.09 .2019$

Accepted 14.11.2019

Doi: 10.30939/ijastech..526392

\section{Introduction}

The helical gears are used very frequently in many mechanical constructs $[6,8,9,10,11,12,13]$. The one of the main applications is on the gear transmissions of vehicles (Figure 1).

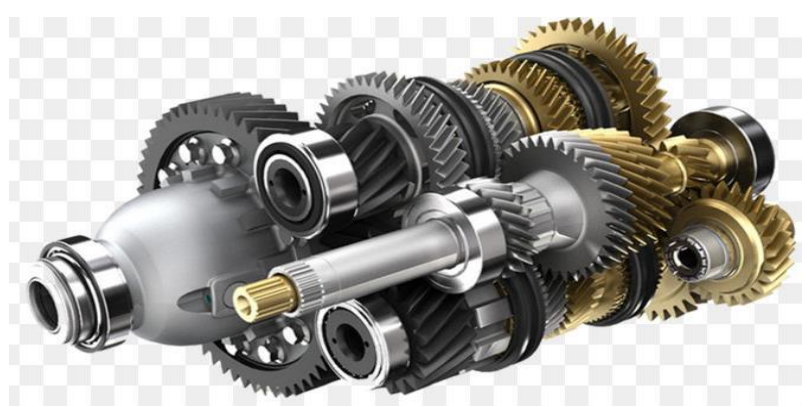

Fig. 1. A Volkswagen gear transmission [14]

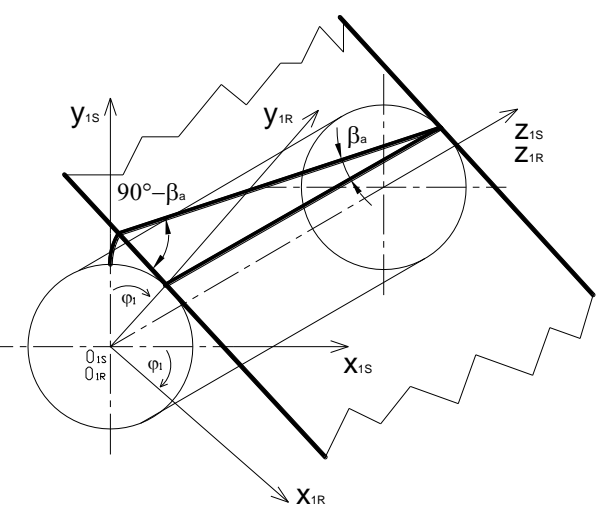

Fig 2. The derivation of the involute surface $[1,6]$

The teeth are picked up the loads at the same time and ceased at the same time. The connection is continuously. The force effects from the friction are worked into two directions on the same tooth. Based on this the helical gear is run more 
silently $[2,3,5,6,11]$.

The disadvantage is the axial force which could be compensated by Herringbone gear [6].

Based on Figure 2. a tangential plane is turned around the basic cylinder on the $\mathrm{K}_{1 \mathrm{R}}$ rotation coordinate system. The basic cylinder is situated on the $\mathrm{K}_{1 \mathrm{~S}}$ standing coordination system. This is the derivation of the involute helical surface (Figure 2.). $[1,6]$ An arbitrary oblique line of this tangential plane is describe an involute helical surface. Every planar section of this is verdant involute. The tangential plane of the basic cylinder is the connection plane (Figure 3 ) $[3,5,6]$.

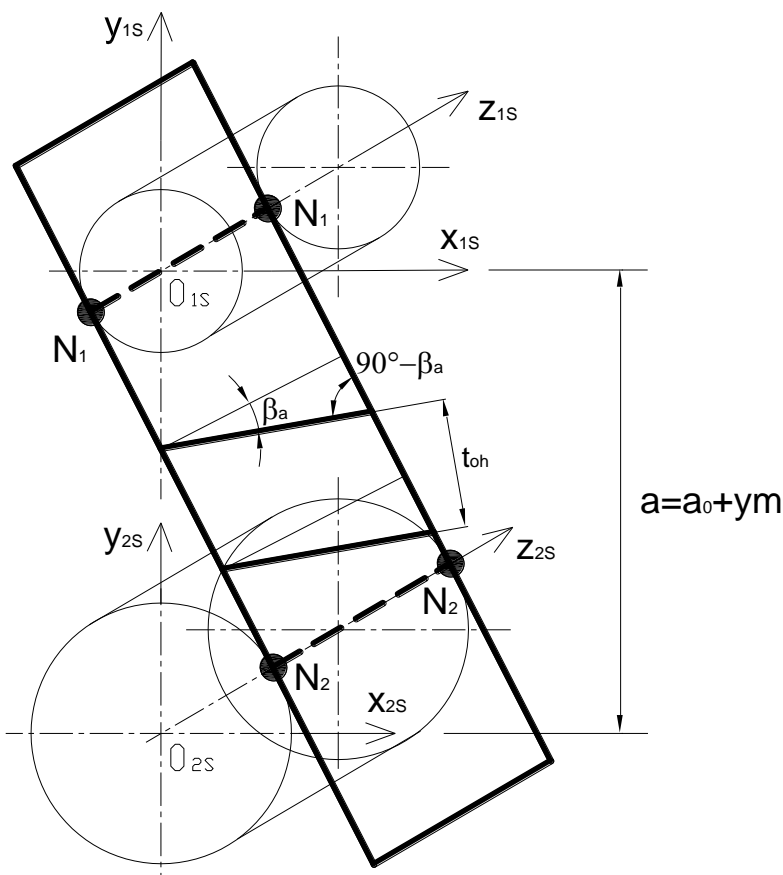

Fig. 3. The basic cylinders of the involute helical surfaces [1, 6]

The generator of the tooth surface is closed $\beta_{\mathrm{a}}$ angle with the axis of the basic cylinder. The $\left(90^{\circ}-\beta_{\mathrm{a}}\right)$ is the helix angle of the involute helical surface $[3,5,6,7]$.

\section{Designing of the $x$-zero helical gear pairs}

The basic property of the x-zero gear drives is the connection is done on the pitch circle diameter, that is why the pitch circle diameter and the rolling circle diameter are the same $[3,5,6]$ :

$$
\left.\begin{array}{c}
a_{o}=\frac{d_{1}+d_{2}}{2} \\
d_{1}=d_{w 1} \\
d_{2}=d_{w 2}
\end{array}\right\}
$$

Knowing of the geometric parameters from the references we have worked out a computer software because of the facilitation of the designing process [1].

We have designed five types of helical gears based on the modification of the tooth trace (Table 1). All of other parameters has been the same, only the tooth trace has been modified on the pitch cylinder $\left(\beta_{0}\right)$ (Figure 4$)$ :

$$
\beta_{a}=\operatorname{asin}\left(\cos \alpha_{0} \cdot \sin \beta_{0}\right)
$$

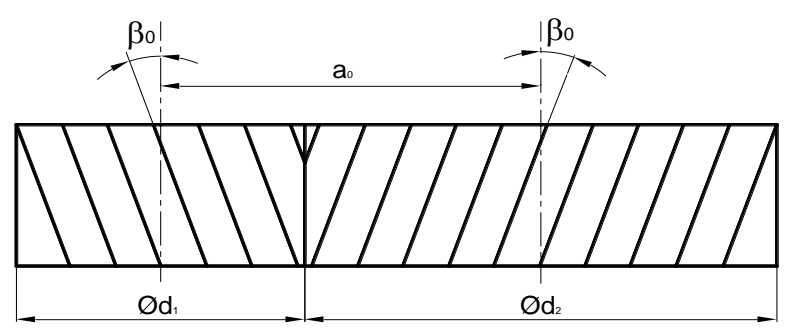

Fig. 4. The position of the $\beta_{0}$ angle

The involute profile angle on the pitch circle:

$$
\alpha_{o h}=\operatorname{acos}\left(\tan \beta_{a} / \tan \beta_{0}\right)
$$

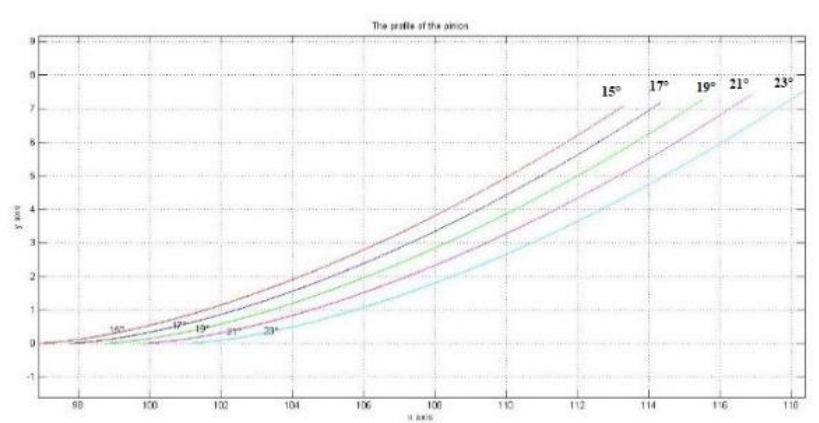

a) The profiles of the pinion

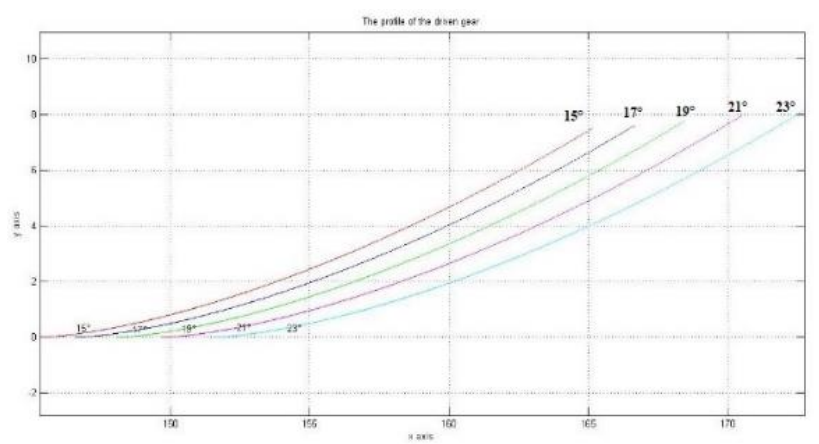

b) The profiles of the driven gear

Fig. 5. The calculated gear profiles in the function of the tooth trace

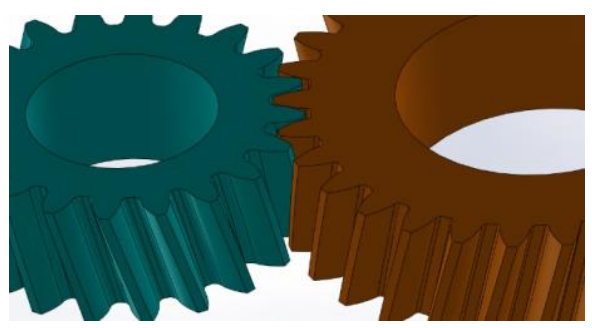

Fig. 6. The CAD models of the designed gear pairs 
Table 1. The parameters of the designed helical gear pairs

\begin{tabular}{|c|c|c|c|c|c|}
\hline & $\begin{array}{l}\text { Gear drive } \\
\text { I. }\end{array}$ & $\begin{array}{l}\text { Gear drive } \\
\text { II. }\end{array}$ & $\begin{array}{l}\text { Gear drive } \\
\text { III. }\end{array}$ & $\begin{array}{l}\text { Gear drive } \\
\text { IV. }\end{array}$ & $\begin{array}{c}\text { Gear drive } \\
\text { V. }\end{array}$ \\
\hline Axial module $(\mathrm{m})[\mathrm{mm}]$ & \multicolumn{5}{|c|}{10} \\
\hline Number of teeth of the pinion $\left(z_{1}\right)$ & \multicolumn{5}{|c|}{20} \\
\hline $\begin{array}{l}\text { Number of teeth of the driven } \\
\text { gear }\left(\mathrm{z}_{2}\right)\end{array}$ & \multicolumn{5}{|c|}{30} \\
\hline Tooth trace $\left(\beta_{0}\right)\left[^{\circ}\right]$ & 15 & 17 & 19 & 21 & 23 \\
\hline Profile angle $\left(\alpha_{0}\right)\left[{ }^{\circ}\right]$ & \multicolumn{5}{|c|}{20} \\
\hline Axial pitch $\left(\mathbf{t}_{0 \mathrm{~h}}\right)[\mathrm{mm}]$ & 32.524 & 32.851 & 33.226 & 33.651 & 34.129 \\
\hline Addendum $\left(\mathbf{h}_{\mathbf{a}}\right)[\mathrm{mm}]$ & \multicolumn{5}{|c|}{10} \\
\hline Bottom clearance $(\mathbf{c})[\mathrm{mm}]$ & \multicolumn{5}{|c|}{2.5} \\
\hline Dedendum $\left(\mathbf{h}_{\mathrm{f}}\right)[\mathrm{mm}]$ & \multicolumn{5}{|c|}{12.5} \\
\hline Whole depth (h) $[\mathrm{mm}]$ & \multicolumn{5}{|c|}{22.5} \\
\hline $\begin{array}{l}\text { Pitch circle diameter of the pinion (d } \\
\text { 1) }[\mathrm{mm}]\end{array}$ & 207.055 & 209.138 & 211.524 & 214.229 & 217.272 \\
\hline $\begin{array}{l}\text { Pitch circle diameter of the driven } \\
\text { gear }\left(d_{2}\right)[\mathrm{mm}]\end{array}$ & 310.582 & 313.707 & 317.286 & 321.343 & 325.908 \\
\hline $\begin{array}{l}\text { Elementary centre distance }\left(\mathbf{a}_{0}\right) \\
{[\mathrm{mm}]}\end{array}$ & 258.819 & 261.422 & 264.405 & 267.786 & 271.590 \\
\hline $\begin{array}{l}\text { Tip circle diameter of the pinion } \\
\text { (da1) }[\mathrm{mm}]\end{array}$ & 227.055 & 229.138 & 231.524 & 234.229 & 237.272 \\
\hline $\begin{array}{l}\text { Tip circle diameter of the driven } \\
\text { gear }\left(d_{a 2}\right)[\mathrm{mm}]\end{array}$ & 330.582 & 333.707 & 337.286 & 341.343 & 345.908 \\
\hline $\begin{array}{l}\text { Root circle diameter of the pinion }\left(\mathrm{d}_{\mathrm{f}}\right. \\
\text { 1) }[\mathrm{mm}]\end{array}$ & 182.055 & 184.138 & 186.524 & 189.229 & 192.272 \\
\hline $\begin{array}{l}\text { Root circle diameter of the driven } \\
\text { gear }\left(d_{\mathbf{f} 2}\right)[\mathrm{mm}]\end{array}$ & 285.582 & 288.707 & 292.286 & 296.343 & 300.908 \\
\hline Backlash $\left(\mathbf{j}_{\mathrm{s}}\right)[\mathrm{mm}]$ & 1.626 & 1.642 & 1.661 & 1.682 & 1.706 \\
\hline Working depth $\left(\mathbf{h}_{w}\right)[\mathrm{mm}]$ & \multicolumn{5}{|c|}{20} \\
\hline Tooth thickness $\left(\mathbf{S}_{\mathrm{ax}}\right)[\mathrm{mm}]$ & 15.449 & 15.604 & 15.782 & 15.984 & 16.211 \\
\hline $\begin{array}{l}\text { Basic circle diameter of the pinion (da } \\
\text { 1) }[\mathrm{mm}]\end{array}$ & 193.756 & 195.460 & 197.403 & 199.596 & 202.050 \\
\hline $\begin{array}{l}\text { Basic circle diameter of the driven ge } \\
\text { ar }\left(d_{a 2}\right)[\mathrm{mm}]\end{array}$ & 290.634 & 293.190 & 296.105 & 299.394 & 303.076 \\
\hline Transmission ratio (i) & \multicolumn{5}{|c|}{1.5} \\
\hline
\end{tabular}

The calculated profiles of the pinion and the driven gear could be seen in the function of the modification of the tooth trace on Figure 5. The involute profile is changed in the function of the modification of the tooth trace.

Knowing of the calculated parameters of the designed gear pairs the CAD (Computer Aided Designing) models of the elements could be prepared by Solidworks software (Figure 6).

Our developed program can export the profile curves of the elements in $t x t$ format. Based on this points interpolated B-spline [4] could be fitted for the points by Solidworks software. After that the CAD models could be built up [1].

\section{Tooth contact analysis (TCA)}

The aim of the TCA is the analysis of the established mechanical parameters of the gear pairs before the production. If the analyzed mechanical parameters are not appropriate there are possibilities for the modification of the ge- ometric parameters of the gears for the better working conditions $[5,7,8]$.

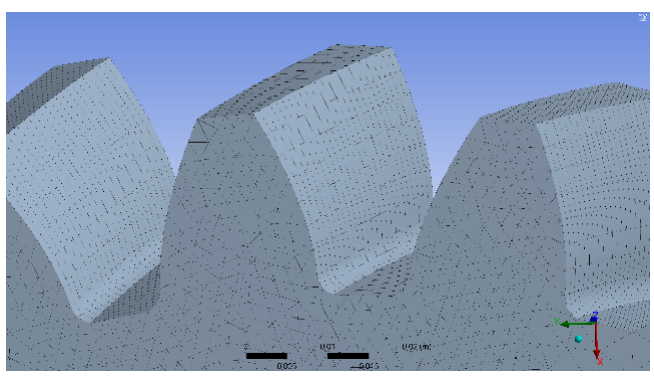

Fig.7. The adoption of the FEM mesh

Face sizing type meshing has been used on the contact zone around a sphere having $35 \mathrm{~mm}$. The type of the plane figure has been a triangle. The applied density of the meshing has been $2 \mathrm{~mm}$ (Figure 7). The meshing has been handed out equally along the tooth length. 
The applied material has been structural steel (Table 2).

Table 2. The parameters of the applied materials

\begin{tabular}{|l|l|}
\hline Density & $7850 \mathrm{~kg} / \mathrm{m}^{3}$ \\
\hline Yield limit & $250 \mathrm{MPa}$ \\
\hline Ultimate strength & $460 \mathrm{MPa}$ \\
\hline
\end{tabular}

\subsection{Defining of the load and boundary conditions}

During the analysis, 3 coordinate systems have been defined: two standing coordinate systems on the middle rotation axes of the gear pairs $\left(\mathrm{K}_{1 \mathrm{~S}}, \mathrm{~K}_{2 \mathrm{~S}}\right)$, one coordinate system on the contact zone of the gears.

All freedom degrees of the driven gear have been fixed. Five freedom degrees of the pinion have been fixed, only the rotation around the axis of rotation has been permitted.

The pinion has been loaded by $500 \mathrm{Nm}$ moment. The contact tooth surfaces of the gear pairs have been analyzed.

\subsection{Analysis of the normal stresses on the tooth surfaces}

The normal stress is defined perpendicularly for the tooth surfaces on the coordinate system on the contact zone of the gears. These direction is the most determinative in aspect of tooth deformation.

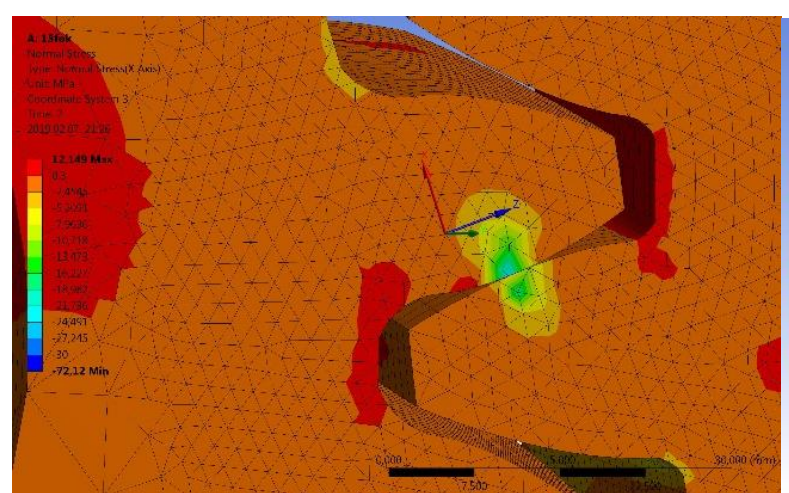

a) contact zone

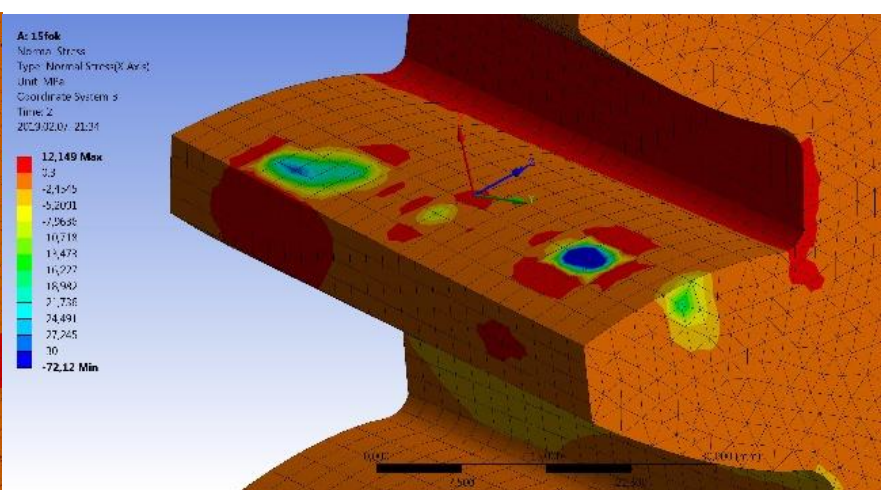

b) tooth surface of the driven gear

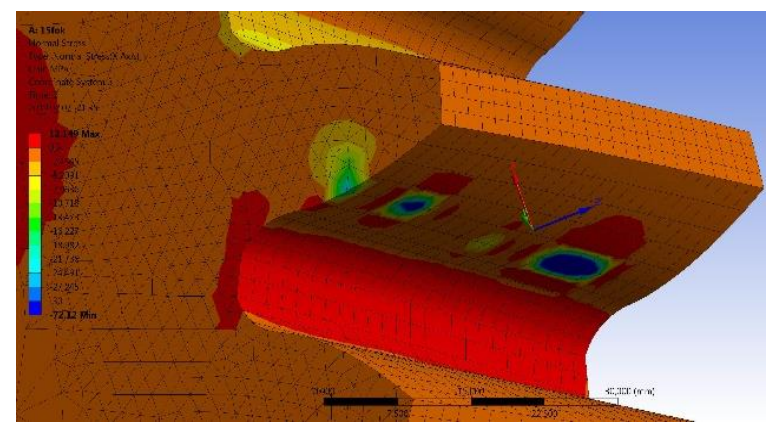

c) tooth surface of the pinion

Fig. 8. Normal stress distribution $\left(\mathrm{m}=10 \mathrm{~mm}, \mathrm{z}_{1}=20, \mathrm{z}_{2}=30, \beta_{0}=15^{\circ}\right)$

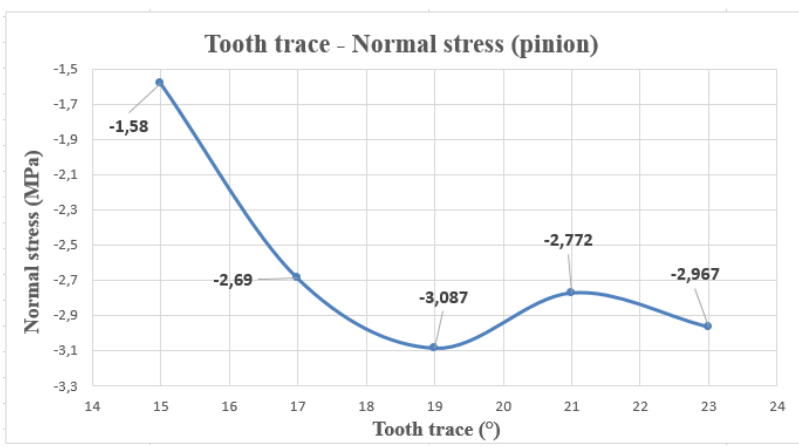

a) pinion

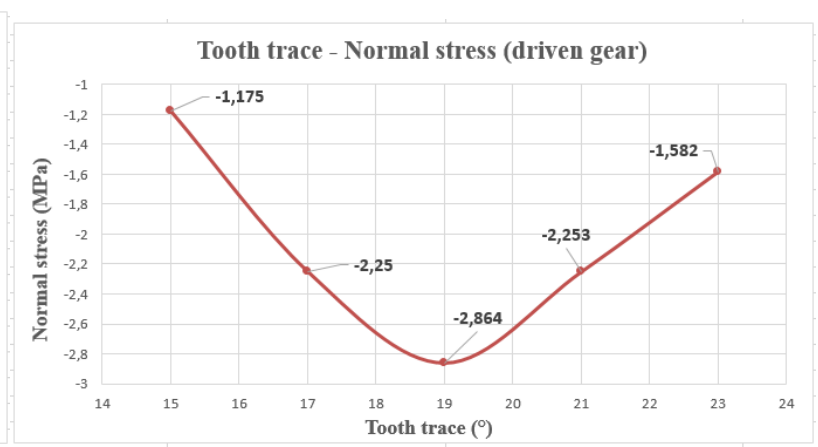

b) driven gear

Fig. 9. The normal stress results in the function of the tooth trace 


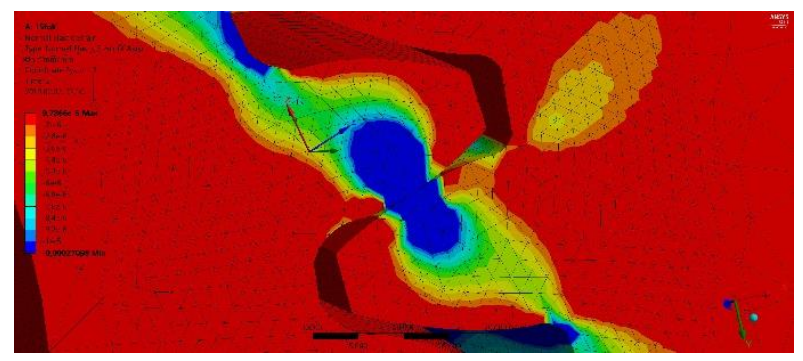

a) contact zone

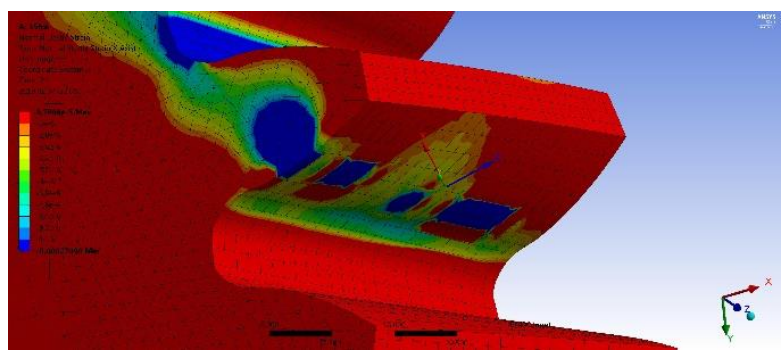

b) tooth surface of the driven gear

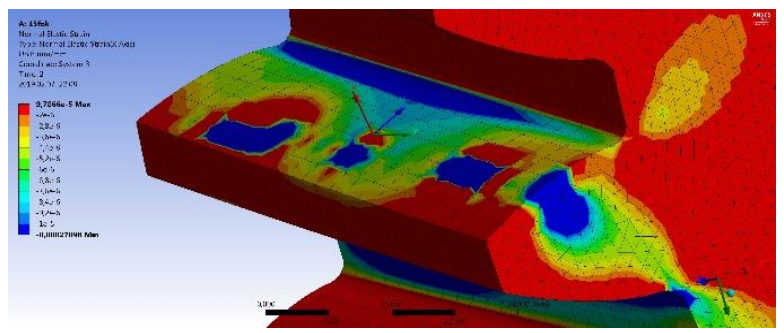

c) tooth surface of the pinion

Fig. 10. Normal elastic strain distribution $\left(\mathrm{m}=10 \mathrm{~mm}, \mathrm{z}_{1}=20, \mathrm{z}_{2}=30, \beta_{0}=15^{\circ}\right)$

The normal elastic strain is determined perpendicularly for the tooth contact surface. This direction is the most determinable in the tooth connection.

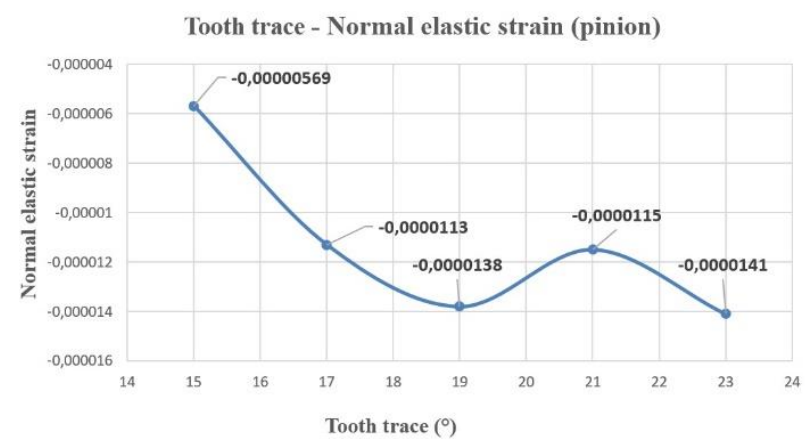

a) pinion

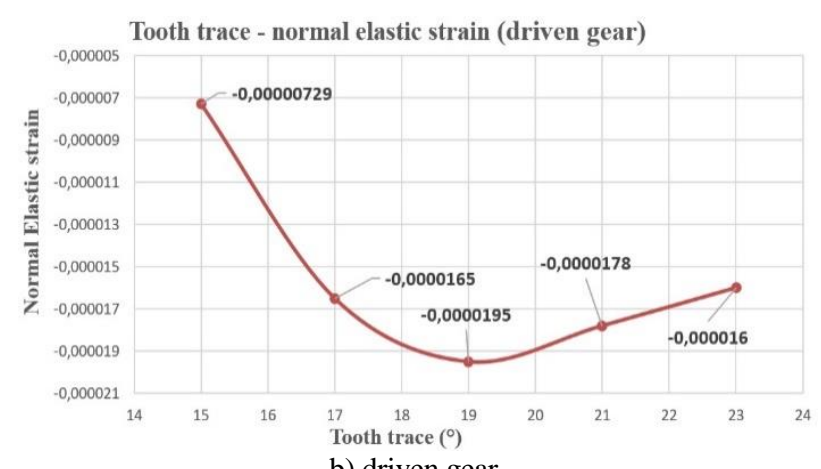

b) driven gear

Fig. 11. The normal stress results in the function of the tooth trace

\subsection{Analysis of the normal deformation on the tooth sur- faces}

The deformation could be determinable to many directions. In case of the tooth connection the main direction is the normal direction which is perpendicular for the contact surfaces. It could be determined by the help of the coordinate system on the contact zone of the gears (Figure 12.a).

The normal stress results in the function of the tooth trace could be seen on Figure 9.

A little fluctuation could be seen on the pinion side (Figure 9.a). The lowest normal stress in absolute value could be achieved in case of Gear drive I.

The normal stress is increased until $\beta_{0}=19^{\circ}$ tooth trace. After that the normal stress is started decreasing (Figure 9.b) on the driven gear side. The lowest normal stress in absolute value could be achieved in case of Gear drive I.

According to the normal stress distribution the Gear drive I has better stress results.

The normal elastic strain results in the function of the tooth trace could be seen on Figure 11.

The lowest result could be found in case of $\beta_{0}=15^{\circ}$ in absolute value on the pinion (Figure 11.a). The highest result could be found in case of $\beta_{0}=23^{\circ}$ in absolute value.

The lowest result could be found in case of $\beta_{0}=15^{\circ}$ in absolute value on the driven gear (Figure 11.b). The highest result could be found in case of $\beta_{0}=19^{\circ}$ in absolute value.

According to the normal elastic strain distribution the Gear drive I has better results beside the constancy of the other gear parameters (Figure 11).

The normal deformation results in the function of the tooth trace could be seen on Figure 13. 


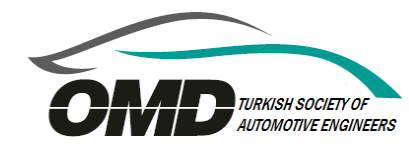

The lowest result could be found in case of $\beta_{0}=21^{\circ}$ in absolute value on the pinion (Figure 13.a). The highest result could be appeared in case of $\beta_{0}=17^{\circ}$ in absolute value. This value is outstanding high than the other deformation values.

The lowest result could be found in case of $\beta_{0}=15^{\circ}$ in absolute value on the driven gear (Figure 13.b). The highest result could be appeared in case of $\beta_{0}=19^{\circ}$ in absolute value.

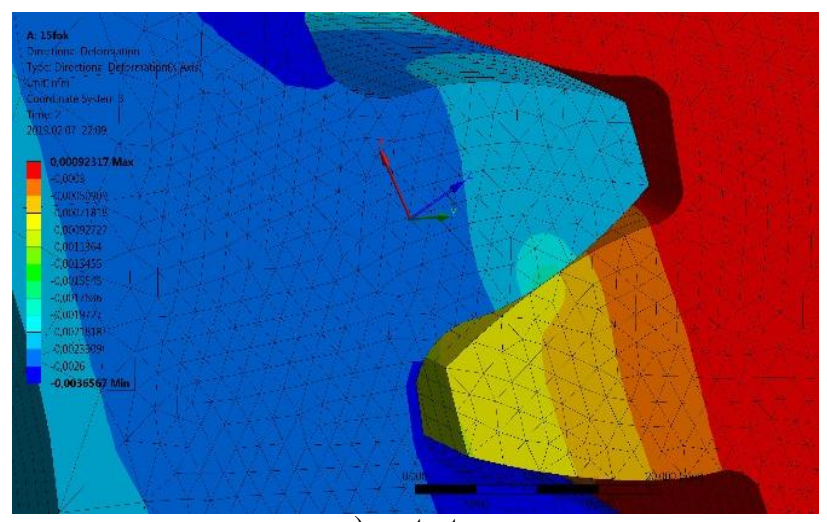

a) contact zone

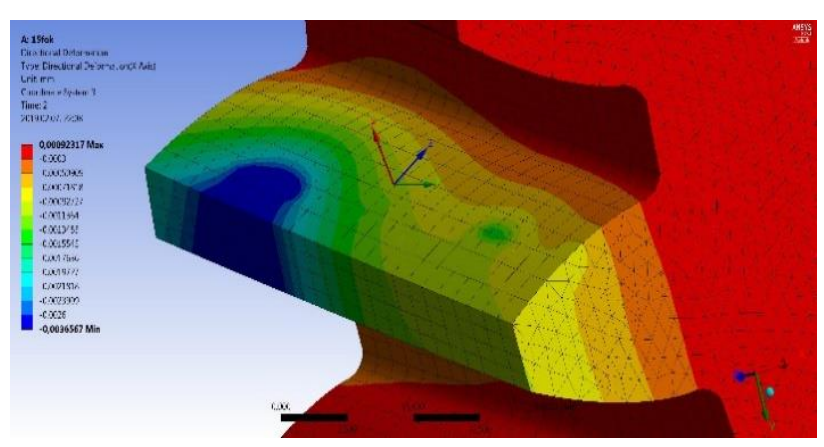

b) tooth surface of the driven gear

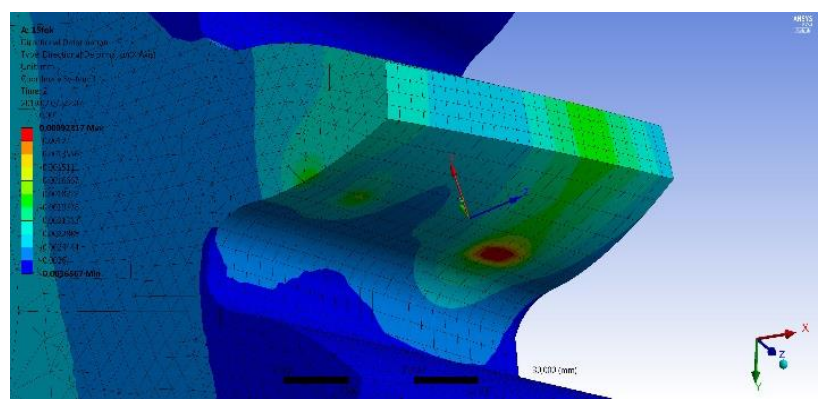

c) tooth surface of the pinion

Fig. 12. Normal deformation distribution $\left(\mathrm{m}=10 \mathrm{~mm}, \mathrm{z}_{1}=20, \mathrm{z}_{2}=30, \beta_{0}=15^{\circ}\right)$

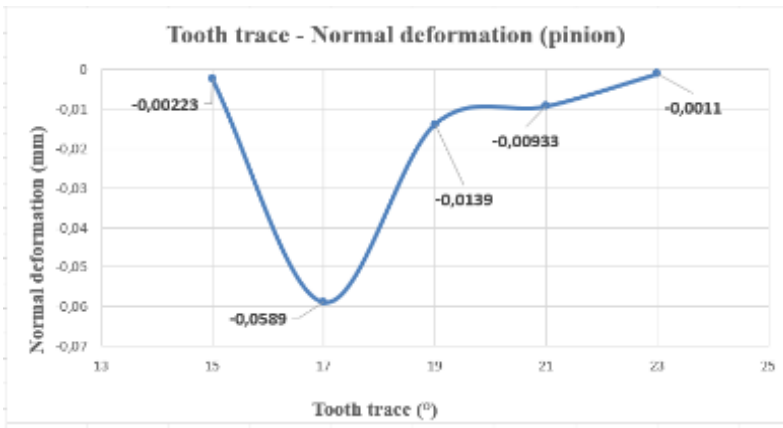

a) pinion

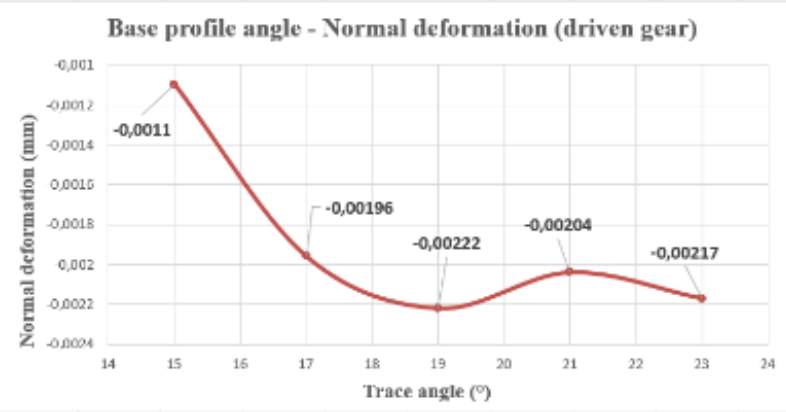

b) driven gear

Fig. 13. The normal deformation results in the function of the tooth trace

\section{Conclusions}

The helical gear pairs are used in many mechanical constructions for instance vehicle's gear transmissions or working machines. The TCA is important because of the achievement of better mechanical conditions during the working. The modification of the geometric parameters of the gear pairs is important due to the optimized TCA's results.

Five types of $x$-zero helical gear pairs have been designed. Only the tooth trace has been modified during the designing process. We have worked out a computer program with which the designing process could be easier. After the designing process the CAD models and the assembly construction could be created for the TCA.

TCA has been done for the analysis of the normal stresses, normal deformations and normal elastic strains. Our purpose is the comparative analysis of the TCA's results in the function of the modification of the tooth trace on the tooth contact zone. After that the correlations between the modified gear parameters and the TCA results could be determinable.

Based on our results we could achieve better TCA' results if we apply lower tooth trace beside the constancy of other gear parameters. 


\section{Acknowledgment}

\section{를 \\ EMBERI ERÖForrásoK
MINISZTÉRIUMA NATIONAL EXCELLENCE PROGRAM OF THE MiNISTRY OF HUMAN CAPACITIES"}

This research was supported by the János Bolyai Research Scholarship of the Hungarian Academy of Sciences.

\section{Nomenclature}

$\beta_{0}$

$\beta_{\mathrm{a}} \quad:$ the tooth trace on the basic cylinder ( )

$\mathrm{K}_{\mathrm{S}}\left(\mathrm{x}_{\mathrm{S}}, \mathrm{y}_{\mathrm{S}}, \mathrm{z}_{\mathrm{S}}\right)$ : the stationary coordinate system of the helical gear

$\mathrm{K}_{\mathrm{R}}\left(\mathrm{x}_{\mathrm{R}}, \mathrm{y}_{\mathrm{R}}, \mathrm{z}_{\mathrm{R}}\right)$ : the stationary coordinate system of the helical gear

: angular displacement $\left({ }^{\circ}\right)$

: centre distance $(\mathrm{mm})$

: elementary centre distance $(\mathrm{mm})$

: specific increase of centre distance

: axial module $(\mathrm{mm})$

: profile angle $\left(^{\circ}\right)$

: axial pitch $(\mathrm{mm})$

: addendum [mm]

: dedendum $[\mathrm{mm}]$

: whole depth [mm]

: pitch circle diameters (mm)

: tip circle diameters (mm)

: root circle diameters $(\mathrm{mm})$

: rolling circle diameters $(\mathrm{mm})$

: backlash (mm)

: working length (mm)

: tooth thickness $(\mathrm{mm})$

: basic circle diameters $(\mathrm{mm})$

: transmission ratio

: number of teeth

\section{References}

[1] Bodzás, S. (2018). Ferde fogazatú fogaskerékpárok számítógéppel segített tervezése és modellezése, Müszaki Tudomány az Észak - Kelet Magyarországi Régióban 2018 Konferencia Elöadásai, Debreceni Akadémiai Bizottság, Müszaki Szakbizottság, 25-41, ISBN 978-963-7064-37-1

[2] Dudás, I. (2011). Gépgyártástechnológia III., A. Megmunkáló eljárások és szerszámaik, B. Fogazott alkatrészek gyártása és szerszámaik, Müszaki Kiadó, Budapest, 2011.

[3] Erney, Gy. (1983). Fogaskerekek, Müszaki Könyvkiadó, Budapest, p. 460.

[4] Juhász, I. (1995). Számitógépi geometria és grafika, Miskolci Egyetemi Kiadó, Miskolc, p. 220

[5] Litvin, F. L., Fuentes, A. (2004). Gear Geometry and Applied Theory, Cambridge University Press, ISBN 978052181517 8

[6] Terplán, Z. (1975). Gépelemek IV., Kézirat, Tankönyvkiadó, Budapest, p. 220.

[7] Litvin, F. L., Fuentes, A., Gonzalez-Perez, I., Carnevali, L., Sep, T. M. (2002). New version of Novikov-Wildhaber, helical gears: computerized design, simulation of meshing and stress analysis, Computer Methods in Applied Mechanics and Engineering, Elsevier, 5707 - 5740

[8] Fuentes, A., Ruiz-Orzaez, R., Gonzalez Perez, I. (2014). Computerized design, simulation of meshing and finite element analysis of two types of geometry of curvilinear cylindrical gears, Computer Methods in Applied Mechanics and Engineering, Elsevier, $321-339$.

[9] Jing, W., Aiqiang, Z., Gangqiang, W., Datong, Q., Teik, C. L., Yawen W., Tengjiao L. (2018). A study of nonlinear excitation modeling of helical gears with Modification: Theoretical analysis and experiments, Mechanism and Machine Theory, Elsevier, 314-335

[10]Mo, S., Ma, S., Jin, G., Gong J., Zhang, T., Zhu, S. (2018). Design principle and modeling method of asymmetric involute internal helical gears, Journal of Mechanical Engineering Science, 1-12, DOI: 10.1177/0954406218756443

[11]Yanjun, P., Ning, Z., Pengyuan, Q., Mengqi, Z., Wang, L., Ruchuan, Z. (2018). An efficient model of load distribution for helical gears with modification and misalignment, Mechanism and Machine Theory, Elsevier, 151-168

[12]Radu George C., Sorin C. (2018). Contact analysis of helical gears by using finite element method, Proceedings of 2018 International Conference on Hydraulics and Pneumatics, Băile Govora, Romania, 172-176, ISSN 1454 - 8003

[13]Yifan H., Kangkang C., Hui M., Linyang C., Zhanwei L., Bangchun W. (2019). Deformation and meshing stiffness analysis of cracked helical gear pairs, Engineering Failure Analysis, 30-46

[14]https://www.kisspng.com/png-mechanical-gear-2649/ 